\title{
Does exchange rate effects the trade balances really? Ev- idence from Pakistan
}

\author{
Faisal Asghar ${ }^{1 *}$, Mubeen Asif ${ }^{2}$, Muhammad Haseeb Aslam ${ }^{3}$, Rao Qamar Bahadur 4 , \\ Khalid Mahmood ${ }^{5}$ \\ ${ }^{1}$ Government College University Faisalabad Allama Iqbal Road, Faisalabad, Pakistan \\ ${ }^{2}$ School of Public Affairs, University of Science and Technology of China, Hefei Anhui, China \\ 1, 3, 4, 5 Office of the Treasury, Government College University Faisalabad Allama Iqbal Road, Faisalabad, Pakistan
}

\begin{abstract}
Keywords
ER

Inflation

Pakistan

Trade deficit

Received: 6 November 2019

Accepted: 9 January 2020

Published: 8 April 2020
\end{abstract}

\begin{abstract}
Exchange Rate (ER) stability is an important factor in determining the economic position of an economy. Speculation in the exchange rate shows the poor performance of a country. A change in the exchange rate may affect the inflation as well as interest rate in the country, and Pakistan is not an exception to this relationship. In this paper, we have tried to examine the impact of the exchange rate on the trade balance. We used the data for 30 years and tested the relationship with the help of correlation and regression. The findings show that Pakistan is continuously facing a trade balance deficit, and the correlation is highly negative. This means that the small open economy of Pakistan has a low saving rate, and thus, NX (the trade balance) is negative. This is due to the continuous depreciation of currency or, in other words, due to an increase in the exchange rate. Continuously increasing in the exchange rate causes the increase in the interest rate, and this cause less saving in which import increase to fulfill the investment gap and thus our trade balance goes to negative.
\end{abstract}

(c) 2020 The Author(s). Published by TAF Publishing.

\section{INTRODUCTION}

This paper tries to investigate the effect of ER on Trade Balance (TB) in Pakistan economy for the period 1983 to 2014. The ER is as important as backbone variable of the TB that plays an important role in the determination of trade balance, while fluctuations in the exchange rate cause the slow process of trade activities and movement of capital and discourage the investor confidence. TB determines the net export and import in a country. It is an important economic factor of our GPD and change in exchange rate strongly affects the balance of trade (Asif, Shah, Zaman, \& Rashid, 2011; Ta echaubol, 2017).

This study tries to investigate the relationship among TB and ER. We applied the statistical test of regression and cointegration by using the open economy model to find out the effect of ER on Pakistan's TB. In an open economy, saving and investment play a vital role to determine the balance of trade; either it is going negative or positive. Despite the relevance of such information, only some studies have investigated how real exchange rate changes impact the trade balance in the Pakistan context.

Pakistan uses a managed floating exchange rate where demand and supply of currency play a vital role, as well as the role of the government, is an important factor. The relationship among TB and ER is very rare and interesting phenomena. Pakistan is the least developing country, so the change in the exchange rate in Pakistan is very speculative. That creates a huge tension for the investor. The issue of possible relation among Balance of trade and exchange rate is extensively studied by the Economist, academia, Policy Makers, intellectuals and Researcher (Alagidede \& Ibrahim, 2017; Arize, Malindretos, \& Igwe, 2017; Devia SS, 2019; Iyke \& Ho, 2017; Khan, Ali, \& Ali, 2016; Li \& Wang, 2015). Rose (1990) while studying the five OECD countries discovered an em-

\footnotetext{
${ }^{*}$ corresponding author: Faisal Asghar

†email: faisal_beaconite@hotmail.com
} 
pirical relationship between the exchange rate and trade balance. The outcomes of his investigation revealed that the exchange rate is an insignificant determinant of trade balance. Similarly Rose and Yellen (1989) found similar results while studying the relationship among TB and ER. Hypothetically, the ER is imperative in financial exercises for no less than two reasons. To start with, changes in the exchange rate (depreciation and appreciation) affect the course of exchange (for example imports and exports). If a nation's exchange rate devaluation, different variables unaltered, the services and goods become less expensive in respect to those of her exchange accomplices. Consequently, the nation should encounter a flood in its fares (Sekkat \& Varoudakis, 2000). On the other hand, if a nation's exchange rate appreciates, at that point the nation's products and ventures become costly, prompting a flood in imports (Salehi-Isfahani, 1989). Second, an insecure exchange rate makes vulnerability, which may deliver unwanted results and outcomes. For the most part, financial specialists will be less persuaded to put resources into an economy with high exchange rate vulnerability (Servén, 2003). Though Aizenman (1992) has appeared ostensible exchange rate vulnerability is bound to dishearten speculation than genuine vulnerability. Servén (2003) has demonstrated that the effect of exchange rate vulnerability on creating nations, specifically, relies upon their level of receptiveness to exchange. Progressively open creating nations experience the ill effects of exchange rate vulnerability. Moreover, Bacchetta and Van Wincoop (2000) have discovered that the extent of net capital streams is higher under an increasingly steady exchange rate administration.

Aziz (2008) tells us the role of exchange rate with balance of trade by using co-integration, Vector Auto-Regressive (VAR) model, Impulse Response Function (IRF), Granger Casualty, the purpose of using these tools to know the effect of ER on the Bangladesh TB and to estimate the long run cointegration among TB and ER. The outcomes demonstrate that there are significant effects of real ER on Bangladeshi TB. Shirvani and Wilbratte (1997) determine the relationship of TB and ER by utilizing the multivariate co-integration based on bilateral trade US and G7 countries 'this paper concludes that there is the existence of long-run relationship among the TB and ER by utilizing the JohansenJulius multivariate cointegration method. In the context of bilateral trade among the USA and G7 countries, the result also shows that the ER also affects the TB in long run empirical validity of the Marshall-Lerner condition.

ER correlates with the trade balance or change in the trade balance cause the fluctuation in exchange rate or vice versa in Pakistani economy, what impacts the trade balance when there comes the change in the Pakistan saving or investment these are the core finding and purpose of this paper. To achieve the target, the work is structured as follows. The authors define key concepts and theoretical background of the article. Then, the material and methods are presented. Finally, the empirical study is presented with results and discussion followed by the conclusions.

\section{LITERATURE REVIEW}

The past man years have seen impressive research concerning the relationship between the TB and ER, and much have composed on both the empirical and theoretical approaches of the problem. Though, no compact ends have risen. From the vast majority of the investigations alluded to beforehand, we suspect that the connection among TB and ER have accepted as symmetrical in nature. That is, the conduct of the TB and ER changes is thought to be the equivalent for money deterioration for what it's worth for cash appreciation. Asymmetry can happen at the time when negative and positive deviations return in the speed of inversion among negative and positive deviances from harmony once they cooperate with each other in a non-linear way (Arize \& Malindretos, 2012). From the previous studies, a linear model with their inferred symmetry has utilized to contend that a similar speediness of modification occurs in the alteration course among TB and ER changes. A few investigations, including yet not restricted to Arize and Malindretos (2012), Kapetanios, Shin, and Snell (2003), Nam, Pyun, and Arize (2002), Nam, Kim, and Arize (2006), Pascalau (2007), Sollis (2009), Sollis, Leybourne, and Newbold (2002), have revealed that financial and economic factors can create nonlinearities and asymmetries. These asymmetry discoveries are essential since, as clarified prior, they demonstrate that alert ought to be practiced in deciphering the exact outcomes that expect symmetry in light of the fact that both mistakes and bias are progressively to be expected in such a system.

In the current investigation, we investigate the reaction of the TB is symmetric to deviations in the real ER. The reason for the likelihood of unbalanced developments of the TB just as deviated exchange balance alteration can be found in later hypothetical works (Alatrash, 2018; Dixit, 1989) on hysteretic conduct, or disappointment of an impact to be turned around once the reason for the unsettling influence is evacuated. Export organizations need to contribute afore they could trade their products in a different nation, and a developed pledge to trade marketplaces mirrors an advanced goal to allocate managerial, monetary and social 
assets to export movement. Subsequently, a commercial philosophy introduction in the direction of export happens done such as, the improvement of significant worth including administrations for consumer loyalty and faithfulness. A portion of these investments might be in capital investment, distribution and relocation systems (item and procedure adjustments and universal affirmations), infrastructure and research and development. The expense of the reserves can't be recovered when the firm chooses to quit the actions of export. For example, accepting that fresh export organizations arrive at market amid money devaluation, the company's sunken entrance and leave costs increment, which makes dithering to recover the expense of their reserves once the deterioration is finished. Their conduct turns into the "hold your breath and trust in better times soon" kind in the event that they stay in the market once the money increases in value. Subsequently, gain in exchange is anticipated, that infers the degree of expansion in trade income within money obligation is required than expansion in a devaluation. This is on the grounds that, confronting as of late incoming trade contenders, the trade income of built up businessmen cannot increment to the extent that will happen, when no contestants.

In entirety, if businessmen could not leave marketplace once residential cash reinforced the trade income of the ongoing and set up businessmen will presumably diminish. Unequal impacts of cash deterioration on exports and imports could be with the end goal that export income can be generally minor amid devaluation periods, though trade income may even diminish as household money increases in value. Asymmetries and nonlinearity have been credited to value stickiness. According to Peltzman (2000), he contends that "costs rise quicker than they reduce." Organizations increase costs quicker once expenses rise and they decrease costs once expenses reduce. Costs are progressively pasty (moderate to modification) down than up, and amounts are unbending up. Rhee and Rich (1995) establish proof for the adhesiveness of costs. The decision makers will in general change item costs more rapidly to increments in expense than they do to diminish in expense.

The approach concern of whether to intercede can prompt nonlinearities and irregularities. Approved ER mediation activities (purchasing and marketing outside trade beside their very own cash so as to influence the swapping scale) or declarations of 'oral intercessions' might hasty to irregular economic situations meanwhile they make vulnerability in the showcase regarding the long run estimation of the ER. However, the fundamental idea is that mediation endeavors to take care of a matching issue in the remote trade showcase among monetary authorities and informed traders. For example, money related experts might be more enthusiastic to endure money indebtedness than deterioration. Therefore, irregular reactions occur in light of the fact that money decreases, there is an inclination for NB to trade its property of outside stores to limit the impacts of money devaluation. Conversely, such intervention outcomes in the market regarding the long run estimation of ER. This prompts offers of remote trade saves amid times of devaluation, which thusly makes more noteworthy market vulnerability and instability in future years. Possibly more noteworthy and of specific pertinence to this investigation is the thing that occurred ensuing China's Yuan reduction of eleventh of Aug. 2015, biggest beside the United States $\$$ in over 20 years, that in a split second made Chinese merchandise increasingly focused with American items. Interestingly, when money rises, the national bank may potentially endeavor to revamp its remote trade stores or it might do nothing. In this manner, shudders to the marketplace of equivalent size would prompt distinctive results depends on in what way they identify with ER depreciation or appreciation.

Asymmetries \& nonlinearity can emerge on the grounds that market members have distinctive convictions concerning the genuine harmony dimension of the nominal ER and level of ER conflict, particularly in creating financial prudence where data boundaries and management confinements regularly offer ascent to diversity of sentiments on the FEM. As the ER veers off more far from its harmony level, advertise members achieve agreement about the proper heading of the ER developments, therefore, the ER returns to its dormant dimension (Kilian \& Taylor, 2003).

Irregular reactions are conceivable within the sight of unequal estimating to market conduct. Then estimating to market infers cost segregation crosswise export purpose by exporting organizations, these organizations consider the level of rivalry in outside business sectors prior to adjusting their costs. Looked with money deterioration, exporters will in general keeping up their existing costs and not attempt to increase extra benefits. In doing as such, their overseas money costs are brought down, bringing about an expansion in market share and sales volume which may develop after some time. Thusly, earnings or export income may demonstrate some enhancement, in spite of the fact that insufficient to cover costs and benefits. This conduct design drives exporters to get the shares of the market amid the cash debilitating through cost intensity once lesser costs are related with lesser prices. However, under specific surroundings, there might be no expansion in trade income and 
costs might greater with cash deterioration. The ultimate result is an observational problem.

Whereas, when looked with rise in currency, exporters who plan to reserve and get share of the market in trade fairs would endeavor to decrease markups and EP. Generally, exporters respond by diminishing the residential cash cost of the merchandise sold in order to keep the comparing remote cash costs from growing and subsequent decrease of the share in market. In such manner, exporters trust that saving and not raising oversea money costs is abundantly liked to losing market share and sales volume. Thus, decreased net revenues and shortfall in intensity are acknowledged. This may somewhat clarify why exporters for the most part resort to PIM with an end goal to relatively balance the misfortune in intensity that outcomes from the cash indebtedness. Entirety, traders will cost to marketplace and lesser their residential cost to preserve the share in the market. While, if indebtedness is substantial, traders may discover it progressively hard to bring down costs since it infers decreasing net revenues.

\section{RESEARCH METHODOLOGY}

The variable in this study is the exchange rate and balance of trade, (Pearson \& Lee, 1903) Pearson correlation helps to calculate the direction and magnitude of the linear relationship of two variables.

$$
\mathbf{r}=\frac{\mathrm{sp}}{\sqrt{\mathrm{sSxSSy}}}
$$

The identifier of the regression model by Francis Galton, when he published his paper, and it will become a Galton law of regression which was also confirmed by his friend Karl Pearson (Galton, 1886).

$$
y=a+\beta x i
$$

We used the open economy model used by (Mankiw, 2003) which starts with the equilibrium output level is equal to the total Consumption (C) of the economy, total expenditures made on Investment (I) in the economy, total Government expenditures $(G)$ in the Economy and Net Exports (NX). we may write the relationship as:

$$
\boldsymbol{Y}=\boldsymbol{C}+\boldsymbol{I}+\boldsymbol{G}+\boldsymbol{N} \boldsymbol{X}
$$

By rearranging the above equation, we may write as:

$$
\begin{aligned}
& Y-C-G \\
& =I+N X
\end{aligned}
$$

Again the above equation can be written as.

$$
s-I=N X
$$

Where $S$ stands for saving and $I$ investment which is equal to the balance of trade NX.

$$
I=I
$$

In a small open economy, the effect of investment is related to the interest rate.

$$
N X=S-I
$$

So the balance of trade is equal to saving and investment.

\section{RESULTS AND DISCUSSION}

Data has been taken from the state bank of Pakistan, 31 years exchange rate from 1983 to 2014 as well balance of trade and the empirical result shows that: Figure 1. Figure 1 is showing that there is a continuously negative balance of trade in Pakistan. The Figure 2 shows that the exchange rate is continuously increasing in the Pakistani economy. It means Pak rupee is depreciating continuously.

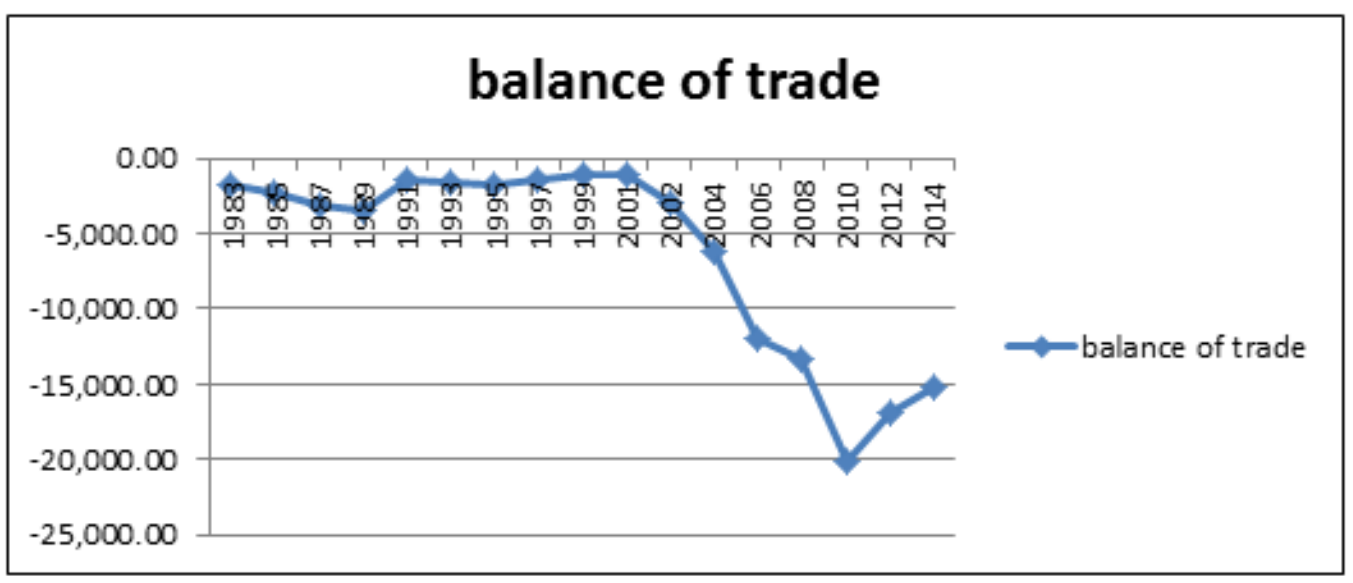

FIGURE 1. Balance of trade of Pakistan 


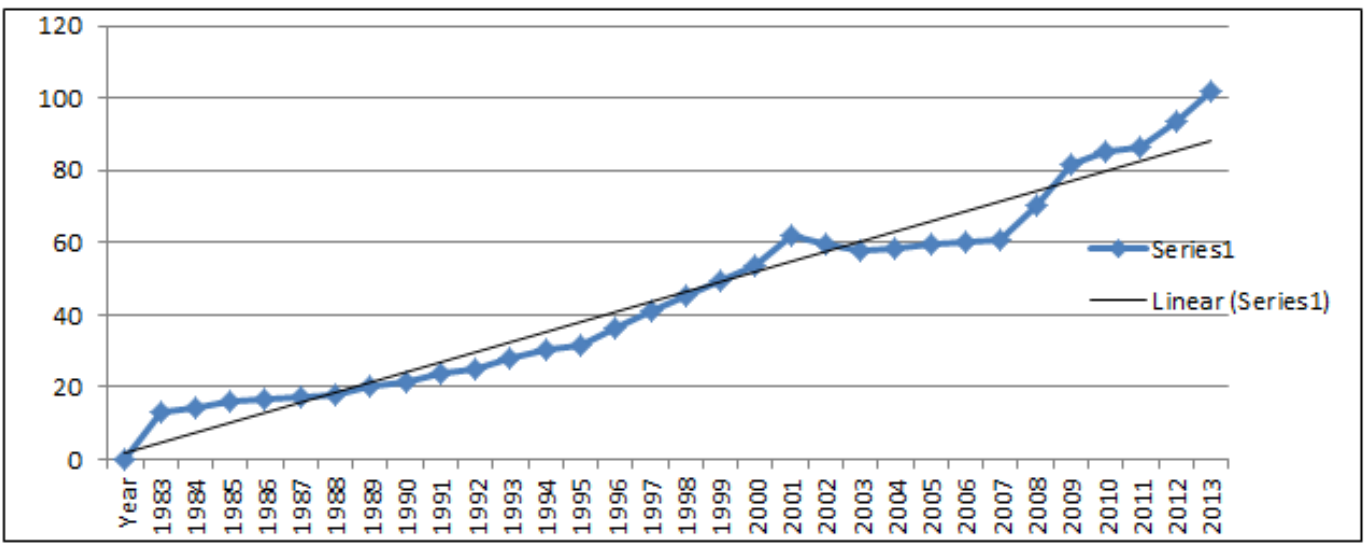

FIGURE 2. ER rrends

TABLE 1. Correlation between trade balance and exchange rate

\begin{tabular}{|c|c|c|c|c|}
\hline & & & TB & Exchange \\
\hline \multirow{3}{*}{\multicolumn{2}{|c|}{ TB }} & Pearson Correlation & 1 & $-.763(* *)$ \\
\hline & & Sig. (2-tailed) & & .000 \\
\hline & & $N$ & 30 & 30 \\
\hline \multirow{3}{*}{\multicolumn{2}{|c|}{ Exchange }} & Pearson Correlation & $-.763(* *)$ & 1 \\
\hline & & Sig. (2-tailed) & & .000 \\
\hline & & $N$ & 30 & 30 \\
\hline Model & $\boldsymbol{R}$ & $R$ Square & Adjusted $R$ Square & Std. The Error of the Estimate \\
\hline 1 & $.763(\mathrm{a})$ & .583 & .555 & 4347.78654 \\
\hline
\end{tabular}

Table 1 shows that the Pearson correlation is negative it means that two variables are linear related to each other and a strongly negative relationship between them. It means that Pakistan exchange rate is going upward and this causes the increase in inflation. This increase in inflation will discourage the saving causing a negative trade balance according to the above equation. When the inflation is in- creased our saving goes to negative, and this causes the negative balance of trade.

Table 2 shows that $F$ value is 20.932, in fact, we have sig level 0 that shows the results are highly significant. So $F$ test rejects the null hypothesis which tells us the linearity in variables.

TABLE 2. Results of $F$ test

\begin{tabular}{lllllll}
\hline \hline Model & & Sum of Squares & $\boldsymbol{d} \boldsymbol{f}$ & Mean Square & $\boldsymbol{F}$ & Sig. \\
\hline 1 & Regression & 395674385.38 & 1 & 395674385.388 & 20.932 & $.000(\mathrm{a})$ \\
& Residual & 283548717.60 & 28 & 18903247.840 & & \\
& Total & 679223102.99 & 29 & & & \\
\hline \hline
\end{tabular}

TABLE 3. Results of correlation

\begin{tabular}{lllllll}
\hline \hline \multirow{2}{*}{ Model } & & \multicolumn{2}{l}{ Un-standardized Coefficients } & Standardized Coefficients & \multicolumn{1}{c}{ S } & \multicolumn{1}{c}{ Sig. } \\
\cline { 3 - 7 } & & $\boldsymbol{B}$ & Std. Error & Beta & B & Std. Error \\
\hline 1 & (Constant) & 12395.123 & 4201.577 & & 2.950 & .010 \\
& ER & -325.610 & 71.170 & -.763 & -4.575 & .000 \\
\hline
\end{tabular}


The above Table shows the similar results that are significant. It shows a negative relationship among balance of trade and exchange rate. It means the negative trade balance gap increase when we increase the exchange rate. This could be because the pace of growth is not according to the required quantity of outputs. Due to the depreciation of the currency, the demand for domestic goods abroad increases because domestic products become less expensive for foreigners, on the other hand, foreign goods become expensive for residents. Due to a shortage of domestic output level and expensive foreign products, the trade balance gap increases.

\section{CONCLUSION}

We conclude the discussion that there is a negative correlation among balance of trade and the exchange rate. This shows that Pakistan is facing a serious problem in exchange rate due to its interest and inflation rate. Pakistan has less saving then its investment it causes the negative trade balance on its economy. Continuously increasing in the exchange rate causes the increase in the interest rate and this cause less saving in which import increase to fulfill the investment gap and thus our trade balance goes to negative.

\section{REFERENCES}

Aizenman, J. (1992). Exchange rate flexibility, volatility, and domestic and foreign direct investment. Staff Papers, 39(4), 890-922. doi:https://doi.org/10.2307/3867425

Alagidede, P., \& Ibrahim, M. (2017). On the causes and effects of exchange rate volatility on economic growth: Evidence from Ghana. Journal of African Business, 18(2), 169-193. doi:https://doi.org/10.1080/15228916.2017.1247330

Alatrash, A. (2018). Impact of using total quality management on the financial performance of companies listed on the Palestine exchange. International Journal of Business and Economic Affairs, 3(6), 244-252. doi:https://doi.org/10 .24088/IJBEA-2018-36001

Arize, A. C., \& Malindretos, J. (2012). Nonstationarity and nonlinearity in inflation rate: Some further evidence. International Review of Economics \& Finance, 24, 224-234. doi:https://doi.org/10.1016/j.iref.2012.02.002

Arize, A. C., Malindretos, J., \& Igwe, E. U. (2017). Do exchange rate changes improve the trade balance: An asymmetric nonlinear cointegration approach. International Review of Economics \& Finance, 49(6), 313-326. doi:https://doi.org/ 10.1016/j.iref.2017.02.007

Asif, M., Shah, S. Q., Zaman, K., \& Rashid, K. (2011). Devaluation and output growth: Evidence from Pakistan. Mediterranean Journal of Social Sciencess, 2(2), 124-130. doi:https://doi.org/10.5901/mjss.2016.v7n4p703

Aziz, N. (2008). The role of exchange rate in trade balance: Empirics from Bangladesh (Unpublished master's thesis). University of Birmingham, Birmingham, UK.

Bacchetta, P., \& Van Wincoop, E. (2000). Does exchange-rate stability increase trade and welfare? American Economic Review, 90(5), 1093-1109. doi:https://doi.org/10.1257/aer.90.5.1093

Devia SS, V. (2019). Analysis of crude oil price and exchange rate volatility on macroeconomic variables (case study of Indonesia as emerging economic country). International Journal of Business and Administrative Studies, 5(5), 257-271. doi:https://dx.doi.org/10.20469/ijbas.5.10001-5

Dixit, A. (1989). Entry and exit decisions under uncertainty. Journal of Political Economy, 97(3), 620-638. doi:https:// doi.org/10.1086/261619

Galton, F. (1886). Family likeness in stature. Proceedings of the Royal Society of London, 40(242-245), 42-73. doi:https:// doi.org/10.1098/rspl.1886.0009

Iyke, B. N., \& Ho, S. Y. (2017). The real exchange rate, the ghanaian trade balance, and the J-curve. Journal of African Business, 18(3), 380-392. doi:https://doi.org/10.1080/15228916.2017.1315706

Kapetanios, G., Shin, Y., \& Snell, A. (2003). Testing for a unit root in the nonlinear STAR framework. Journal of Econometrics, 112(2), 359-379. doi:https://doi.org/10.1016/s0304-4076(02)00202-6

Khan, Z., Ali, A., \& Ali, S. (2016). Impact of devaluation on balance of trade: A case study of Pakistan economy. Asian Journal of Economic Modelling, 4(2), 90-94. doi:https://doi.org/10.18488/journal.8/2016.4.2/8.2.90.94

Kilian, L., \& Taylor, M. P. (2003). Why is it so difficult to beat the random walk forecast of exchange rates? Journal of International Economics, 60(1), 85-107. doi:https://doi.org/10.1016/s0022-1996(02)00060-0

Li, J. T., \& Wang, W. (2015). Predicting exchange rates out of sample: Can economic fundamentals beat the random walk? Journal of Financial Econometrics, 13(2), 293-341. doi:https://doi.org/10.1093/jjfinec/nbu007

Mankiw, N. G. (2003). Macroeconomics new york. New York, NY: Worth Publishers. 
Nam, K., Kim, S.-W., \& Arize, A. C. (2006). Mean reversion of short-horizon stock returns: Asymmetry property. Review of Quantitative Finance and Accounting, 26(2), 137-163. doi:https://doi.org/10.1007/s11156-006-7213-0

Nam, K., Pyun, C. S., \& Arize, A. C. (2002). Asymmetric mean-reversion and contrarian profits: ANST-GARCH approach. Journal of Empirical Finance, 9(5), 563-588. doi:https://doi.org/10.1016/s0927-5398(02)00011-7

Pascalau, R. (2007). Testing for a unit root in the asymmetric nonlinear smooth transition framework (Unpublished master's thesis). Department of Economics, Finance and Legal Studies University of Alabama, Alabama, AL.

Pearson, K., \& Lee, A. (1903). On the laws of inheritance in man: Inheritance of physical characters. Biometrika, 2(4), 357-462. doi:https://doi.org/10.2307/2331507

Peltzman, S. (2000). Prices rise faster than they fall. Journal of Political Economy, 108(3), 466-502. doi:https://doi.org/ $10.1086 / 262126$

Rhee, W., \& Rich, R. W. (1995). Inflation and the asymmetric effects of money on output fluctuations. Journal of Macroeconomics, 17(4), 683-702. doi:https://doi.org/10.1016/0164-0704(95)80089-1

Rose, A. K. (1990). Exchange rates and the trade balance: Some evidence from developing countries. Economics Letters, 34(3), 271-275. doi:https://doi.org/10.1016/0165-1765(90)90130-s

Rose, A. K., \& Yellen, J. L. (1989). Is there a j-curve? Journal of Monetary Economics, 24(1), 53-68. doi:https://doi.org/ 10.1016/0304-3932(89)90016-0

Salehi-Isfahani, D. (1989). Oil exports, real exchange rate appreciation, and demand for imports in Nigeria. Economic Development and Cultural Change, 37(3), 495-512. doi:https://doi.org/10.1086/451739

Sekkat, K., \& Varoudakis, A. (2000). Exchange rate management and manufactured exports in Sub-Saharan Africax. Journal of Development Economics, 61(1), 237-253. doi:https://doi.org/10.1016/s0304-3878(99)00067-x

Servén, L. (2003). Real-exchange-rate uncertainty and private investment in LDCs. Review of Economics and Statistics, 85(1), 212-218. doi:https://doi.org/10.1162/rest.2003.85.1.212

Shirvani, H., \& Wilbratte, B. (1997). The relationship between the real exchange rate and the trade balance: An empirical reassessment. International Economic Journal, 11(1), 39-50. doi:https://doi.org/10.1080/10168739700080003

Sollis, R. (2009). A simple unit root test against asymmetric STAR nonlinearity with an application to real exchange rates in Nordic countries. Economic Modelling, 26(1), 118-125. doi:https://doi.org/10.1016/j.econmod.2008.06.002

Sollis, R., Leybourne, S., \& Newbold, P. (2002). Tests for symmetric and asymmetric nonlinear mean reversion in real exchange rates. Journal of Money, Credit and Banking, 32(7), 686-700. doi:https://doi.org/10.1353/mcb.2002.0007

Taechaubol, K. (2017). Investor types and trading of the environment, social and governance stocks in the stock exchange of Thailand. Journal of Administrative and Business Studies, 3(1), 38-48. doi:https://doi.org/10.20474/jabs-3.1.5 